гии, инженерной геологии и гидрогеологии (2425 марта 2016 г.). М.: РУДН, 2016. С. 289-293.

11. Измеритель магнитного поля ИМП-05. Руководство по эксплуатации ПАЭМ.411173.001РЭ.

12. Промышленность в городе Кимры 2009-2014: информационно-справочное издание. Кимры: АНО «Редакция газеты "Кимры Сегодня"», 2014. 36 с.

13. Коркунов В.И., Коркунов В.В. Страницы истории Кимрского края. Тверь: Марина, 2008. 336 с.

14. Кудинов Н.С. Кимрская земля. Тверь: ООО «Издательство ГЕРС», 2007. 284 с.

15. Методика определения выбросов автотранспорта для проведения сводных расчетов загрязнения атмосферы городов. СПб., 2010.

16. Стадник М.Е. Негативное воздействие компонентов транспортной системы на состояние окружа- ющей среды // Научный диалог. 2013. № 12 (24). C. $38-47$.

17. Даутова М.Б., Жетписбаева Г.Д. Воздействие шума автотранспорта на здоровье населения и меры борьбы с ним в условиях города Алматы // Международный журнал экспериментального образования. 2015. № 11-4. С. 529-531.

18. Кимры [Электронный ресурс] // Bank Gorodov.ru. - http://bankgorodov.ru/place/inform.php?id=2606.

19. Проблемы загрязнения окружающей среды [Электронный ресурс] // Экологический центр «Экосистема». - http://ecosystema.ru/07/zgr.htm.

20. ГН 2.1.7.2511-09. Ориентировочно допустимые концентрации (ОДК) химических веществ в почве.

\title{
OLD CITIES ENVIRONMENT TRANSFORMATION IN THE CONDITIONS OF MODERN TECHNOGENIC INFLUENCE (ECOLOGICAL ANALYSIS OF KIMRY, TVER REGION)
} (C) 2017

Savvateeva Olga Alexandrovna, candidate of biological sciences, associate professor of Ecology and Earth Sciences Department

Arkhipova Elena Vitalievna, candidate of geological and mineralogical sciences, associate professor of Ecology and Earth Sciences Department

Belova Alexandra Nicolaevna, master student of Ecology and Earth Sciences Department

Vlasova Alexandra Andreevna, master student of Ecology and Earth Sciences Department Dubna State University (Dubna, Moscow Region, Russian Federation)

Abstract. The following paper deals with the problem of historic cultural centers environment transformation on the example of Kimry, the Tver Region. The relevance of the research is defined by the fact that technogenic influence of all environment components on urban areas is actually big. The dense population, abundance of multi-storey residential buildings and social objects are combined with intensive traffic flows, existence of the household and industrial enterprises emanated considerable technogenic flows of toxic substances. The paper contains results of a complex analysis of Kimry ecological state, including assessment of soil cover and atmospheric air pollution, magnetic component of technogenic electromagnetic fields of industrial frequency, air aero ionic composition and acoustic influences. The authors show that the maximum technogenic transformation of environmental material and geophysical components is characteristic for the Kimry central part where difficult infrastructure of the modern city is inscribed in tight space of the historic center. Pollution of soil cover and atmospheric air are due to high concentration of transport and imperfection of highways network. Universal existence of electromagnetic smog and change of air aero ionic composition are caused by low layout of city lighting and electrical power supply networks wiring. As a result the authors offer a number of ways how to improve the ecological situation. Division of business parts and cultural parts of old cities and creation of recreational and tourist clusters in the cultural part could be a cardinal solution of the historic centers problem.

Keywords: ecological situation; environmental pollution; technogenic influence; small cities; cultural centers; motor transport; soil cover; electromagnetic smog; aeroions.

УДК $581.9(470.43)$

Статья поступила в редакцию 07.06.2017

\section{ОХРАНЯЕМЫЕ РАСТЕНИЯ НА ТЕРРИТОРИИ ПАМЯТНИКОВ ПРИРОДЫ РАЧЕЙСКОГО ЛЕСНОГО МАССИВА (САМАРСКАЯ ОБЛАСТЬ)}

(C) 2017

Саксонов Сергей Владимирович, доктор биологических наук, профессор,

заместитель директора по научной работе, заведующий лабораторией проблем фиторазнообразия

Васюков Владимир Михайлович, кандидат биологических наук, научный сотрудник лаборатории проблем фиторазнообразия

Институт экологии Волжского бассейна РАН (г. Тольятти, Самарская область, Российская Федерация)

Казанцев Иван Викторович, кандидат биологических наук, декан естественно-географического факультета, доцент кафедры химии, географии и методики их преподавания

Самарский государственный сочиально-педагогический университет (2. Самара, Российская Федераџия)

Сенатор Степан Александрович, кандидат биологических наук,

старший научный сотрудник лаборатории проблем фиторазнообразия

Институт экологии Волжского бассейна РАН (г. Тольятти, Самарская область, Российская Федерация)

Аннотация. Приводится видовой состав раритетных таксонов, произрастающих на особо охраняемых природных территориях регионального значения Самарской области - «Гремячий», «Истоки р. Усы», «Ма- 
лоусинские нагорные сосняки и дубравы», «Рачейская тайга», «Рачейские скалы» и «Семь ключей», расположенных в Рачейском лесном массиве (верховья бассейна р. Уса). Дана оценка их встречаемости на ООПТ. Установлено, что здесь находятся места произрастания 98 видов раритетных сосудистых растений, включенных Красную книгу Самарской области, в том числе 4 видов, занесенных в Красную книгу Российской Федерации (Iris aphylla L., Fritillaria ruthenica Wikstr., Cypripedium calceolus L., Neottiantha cucullata (L.) Schlechter). Еще 17 видов нуждаются в постоянном контроле и наблюдении. Приводимые ранее для бассейна p. Усы Cotoneaster alaunicus Golitsin, Dactyloriza longifolia (L.) Aver. и Jurinea ewersmannii Bunge не обнаружены, их места нахождения в регионе требуют дополнительных исследований. При ревизии раритетных видов растений использованы опубликованные работы, а также неопубликованные материалы полевых исследований, интегрированные в информационно-аналитическую систему Salix. Полученные материалы позволяют предложить корректировку системы памятников природы регионального значения за счет объединения тождественных природно-территориальных комплексов.

Ключевые слова: особо охраняемые природные территории регионального значения; памятники природы; раритетные виды; сосудистые растения; Красная книга Самарской области; информационно-аналитическая система Salix; верховья бассейна реки Уса; Рачейский лесной массив; Самарская область.

Река Уса - правобережный приток Волги (Куйбышевского водохранилища) в ее среднем течении, протекающий по территории Самарской и Ульяновской областей. Исток Усы находится на ВолжскоСвияжском водоразделе недалеко от урочища Гремячий (лесные кварталы 4-6 Балашейского участкового лесничества и лесной квартал 78 Рачейского участкового лесничества) и представляет собой несколько родников, образующих ручьи Большая и Малая Уса.

По данным Государственного водного реестра [1; $2]$, p. Уса имеет протяженность 76 км и водосборную

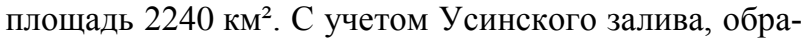
зованного Куйбышевским водохранилищем, длина реки составляет 143 км, а площадь водосборного бас-

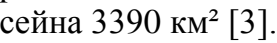

Верхнее течение Усы в пределах Волжско-Свияжского водораздела характеризуется пересеченным рельефом и хорошо развитой лесной растительностью и в системах природного районирования относится к оригинальному выделу Приволжской возвышенности, связанному с деятельностью рек Уса и Свияга [4-6].

Основным элементом растительного покрова верховий Усы являются сосновые, сосново-широколиственные и мелколиственные леса как коренные, так и производные [7], занимающие большую часть водосборного бассейна. Уникальной чертой верховий Усинского бассейна является большая представленность переходных и верховых болот [8], а также обнажения сливного песчаника по склонам долины Усы [9-12] с разнообразным растительным покровом [13-15].

Флористические исследования в этой части p. Усы имеют многолетнюю историю и связаны, прежде всего, с именем Т.И. Плаксиной, ее учениками (О.В. Калашниковой) и ботаниками Самарского

таблица 1 - Памятники природы верховий р. Усы

\begin{tabular}{|c|l|c|c|c|c|c|}
\hline $\begin{array}{c}\text { № } \\
\text { п/п }\end{array}$ & \multicolumn{1}{|c|}{ Название ООПт } & $\begin{array}{c}\text { Место расположения, } \\
\text { кварталы }\end{array}$ & $\begin{array}{c}\text { Дата } \\
\text { основания }\end{array}$ & $\begin{array}{c}\text { Площадь, } \\
\text { га }\end{array}$ & $\begin{array}{c}\text { Источ- } \\
\text { ник }\end{array}$ & $\begin{array}{c}\text { Число раритет- } \\
\text { ных видов* }\end{array}$ \\
\hline 1 & Гремячий & $47,56,62-64,69-71$ & 19.04 .1983 & 445,97 & {$[16]$} & $37 / 4$ \\
\hline 2 & Истоки р. Усы & $4-6 * *, 78$ & 14.06 .1989 & 225,61 & {$[16]$} & $24 / 7$ \\
\hline 3 & $\begin{array}{l}\text { Малоусинские нагорные } \\
\text { сосняки и дубравы }\end{array}$ & 28,3847 & 14.06 .1989 & 279,22 & {$[16]$} & $32 / 7$ \\
\hline 4 & Рачейская тайга & $15,23,25,34-36,43-35$ & 14.06 .1989 & 969,32 & {$[16]$} & $65 / 11$ \\
\hline 5 & Рачейские скалы & $54,61-62$ & 19.04 .1983 & 114,63 & {$[16]$} & $14 / 4$ \\
\hline 6 & Семь ключей & $16,26,37,46$ & 19.04 .1983 & 494,03 & {$[16]$} & $52 / 12$ \\
\hline
\end{tabular}

Примечание. *Число видов, включенных в Красную книгу Самарской области [19] / число видов, нуждающихся в контроле и наблюдении. **Лесные кварталы Балашейского лесничества, остальные памятники природы верховий Усы находятся на территории Рачейского лесничества. государственного педагогического университета (Н.И. Симоновой, В.В. Соловьевой, В.И. Матвеевым, Н.С. Ильиной). Вместе с тем, до настоящего времени полный состав сосудистых растений этой территории так и не выявлен.

Сотрудниками лаборатории проблем фиторазнообразия Института экологии Волжского бассейна РАН в течение 2007-2017 гг. проводились исследования флористического разнообразия памятников природы, расположенных в этой части Усинского бассейна [16, табл. 1]. Данный природный комплекс является интереснейшим во флористическом и природоохранном отношениях, а также важнейшим объектом для формирования представлений о флорогенезе Приволжской возвышенности и юго-востока Европейской части России в целом [17].

Ниже представлены сведения о встречаемости раритетных видов растений, включенных в Красные книги России [18], Самарской области [19], а также реликтовых и краеареальных, по территории памятженных в Рачейском лесном массиве (верховья p. Уca).

Система памятников природы в верховьях Усы начала складываться сразу же после принятия в 1960 г. Закона РСФСР «Об охране природы». Уже в 1967 г. Совет депутатов трудящихся Куйбышевской области принимает постановление о создании памятников природы в Рачейском лесном массиве (Моховое болото, расположенное в бассейне р. Сызранка). Всего в исследуемом районе создано 6 особо охраняемых природных территорий («Гремячий», «Истоки р. Усы», «Малоусинские нагорные сосняки и дубравы», «Рачейская тайга», «Рачейские скалы» и «Семь ключей») (табл. 1), остальные ценные объекты Рачейского лесного массива расположены в бассейне другой реки - Сызранка. ников природы регионального значения, располо- 
При ревизии раритетных видов растений памятников природы верховий бассейна р. Уса использованы опубликованные работы [14; 20-28], а также неопубликованные материалы полевых исследований, интегрированные в информационно-аналитическую систему Salix [29].

Наибольшее число раритетных видов (77) встречается на территории памятника природы «Рачейская тайга», в состав которого входит обширный лесной массив, сложенный различными типами леса, а также моховые и сфагновые болота. Вторую позицию (66 видов) занимает памятник природы «Семь ключей» - территория, сходная с предыдущей в ландшафтном отношении и имеющая с ней общую границу. В связи с этим возникает вопрос, связанный с целесообразностью выделения двух региональных памятников природы, имеющих общие границы и сходный флористический состав. Мы рекомендуем объединить урочища «Рачейская тайга» и «Семь ключей» в единый природно-территориальный охраняемый комплекс.

Аналогично мнение относительно других памятников природы Рачейского лесного массива, расположенных в верховьях бассейна p. Уса. Отсутствует очевидная необходимость выделять в качестве самостоятельных три охраняемых природно-территориальных объекта - «Малоусинские нагорные сосняки и дубравы», «Гремячий» и «Рачейские скалы», представляющих единый ландшафтный комплекс.

В списке раритетных видов растений на территории памятников природы верховий реки Уса (табл. 2) - 115 таксонов, из которых на долю видов, включенных в Красную книгу Самарской области [19], приходится 98, а на виды, нуждающиеся в контроле и наблюдении - 17. Iris aphylla L., Fritillaria ruthenica Wikstr., Cypripedium calceolus L., Neottiantha cucullata (L.) Schlechter имеют федеральный природоохранный статус [18]. Juniperus communis L., повидимому, исчез с изучаемой территории.

Таблица 2 - Раритетные таксоны сосудистых растений на территории памятников природы в верховьях р. Уса

\begin{tabular}{|c|c|c|c|c|c|c|}
\hline \multirow{3}{*}{$\begin{array}{c}\text { Названия растений, } \\
\text { природоохранный статус (по Красной книге Самарской области [19]) }\end{array}$} & \multicolumn{6}{|c|}{ Памятники природы } \\
\hline & 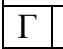 & ИУ & $\mathrm{M}$ & PT & PC & $\mathrm{CK}$ \\
\hline & \multicolumn{6}{|c|}{ Встречаемость } \\
\hline \multicolumn{7}{|l|}{$\begin{array}{l}\text { Покрытосеменные } \\
\text { Adoхасеае }\end{array}$} \\
\hline 1!! Adoxa moschatellina L. (нуждается в контроле) & -1 & III & $\mathrm{I}$ I & II & - & II \\
\hline \multicolumn{7}{|l|}{ Apiaceae } \\
\hline 2 Bupleurum aureum Fisch. ex Hoffm. (КК $\mathrm{CO}-3 / \Gamma$ ) & -1 & - & -1 & - & II & - \\
\hline 3 Bupleurum falcatum L. (KK CO $-3 / \Gamma)$ & III & - & III & - & - & - \\
\hline 4 Cicuta virosa L. (KK CO - 4/0) & - & - & - & II & & II \\
\hline 5 Laser trilobum (L.) Borkh $(\mathrm{KK} \mathrm{CO}-4 / \Gamma)$ & III & II & II & - & III & - \\
\hline $6{ }_{6} \begin{array}{l}\text { Ostericum palustre (Besser) Besser [Angelica palustris (Besser) Hoffm.] } \\
\text { (нуждается в контроле) }\end{array}$ & - & - & - & II & - & II \\
\hline \multicolumn{7}{|l|}{ Araceae } \\
\hline 7 Calla palustris L. (KK $\mathrm{CO}-1 / \Gamma)$ & - & - & -1 & I & - & - \\
\hline \multicolumn{7}{|l|}{ Asteraceae } \\
\hline 8 ! Artemisia sericea Weber ex Stechm. (нуждается в контроле) & II & - & II & - & II & - \\
\hline 9 ! Cirsium heterophyllum (L.) Hill (нуждается в контроле) & - & II & - & III & - & III \\
\hline 10 ! Cirsium oleraceum (L.) Scop. (нуждается в контроле) & -1 & II & - & - & - & II \\
\hline 11 Chondrilla graminea M. Bieb. (KK CO - 3/Г) & III & - & III & - & & III \\
\hline \begin{tabular}{l|l}
12 Helichrysum arenarium (L.) Moench (KK CO $-5 / Б)$ \\
\end{tabular} & III & - & III & - & - & III \\
\hline \multicolumn{7}{|l|}{ Betulaceae } \\
\hline 13! Betula pubescens Ehrh. (нуждается в контроле) & - & II & -1 & III & - & III \\
\hline \multicolumn{7}{|l|}{ Boraginaceae } \\
\hline $14 \mid$ Myosotis popovii Dobrocz. (KK CO $-5 / \Gamma$ ) & -1 & - & III & - & - & III \\
\hline \multicolumn{7}{|l|}{ Campanulaceae } \\
\hline 15 ! Adenophora lilifolia (L.) A. DC. (нуждается в контроле) & II & II & II & - & II & - \\
\hline 16 Campanula cervicaria L. (KK CO $-4 / \Gamma)$ & - & - & - & II & - & II \\
\hline 17 Campanula latifolia $\mathrm{L} .(\mathrm{KK} \mathrm{CO}-5 / \Gamma)$ & -1 & II & -1 & III & - & - \\
\hline 18 Campanula wolgensis P.A. Smirn. (КК CO $-5 / \Gamma$ ) & II & - & II & - & - & - \\
\hline \multicolumn{7}{|l|}{ Caryophyllaceae } \\
\hline 19 Dianthus volgicus Juz. (КK CO $-3 / \Gamma)$ & II & - & II & - & - & - \\
\hline 20 Lychnis chalcedonica L. $(\mathrm{KK} \mathrm{CO}-5 / \Gamma)$ & -1 & - & - & II & - & II \\
\hline \multicolumn{7}{|l|}{ Convallariaceae } \\
\hline 21 Maianthemum bifolium (L.) F.W. Schmidt (KK CO -3/Б) & II & II & II & III & II & III \\
\hline \multicolumn{7}{|l|}{ Cyperaceae } \\
\hline 22 Carex arnellii Christ (KK CO $-1 / 0)$ & -1 & - & - & II & - & - \\
\hline 23 Carex bohemica Schreb. (KK CO - 3/B) & -1 & - & - & II & - & II \\
\hline 24 Carex disticha Huds. (KK $\mathrm{CO}-3 / 0)$ & -1 & - & - & III & - & - \\
\hline 25 ! Carex elongata L. (нуждается в контроле) & -1 & - & - & II & - & II \\
\hline 26 Carex ericetorum Poll. (KK CO $-3 / 0)$ & II & - & II & - & - & II \\
\hline 27 Carex lasiocarpa Ehrh. (KK CO - 2/Б) & - & - & - & III & - & II \\
\hline 28 Carex limosa L. (KK CO $-2 / 0)$ & -1 & - & - & II & - & II \\
\hline 29 Eriophorum angustifolium Honck. [E. polystachion L. nom. rej.] (КK CO - 2/Б) & -1 & - & - & II & - & - \\
\hline 30 Eriophorum gracile W.D.J. Koch (KK CO $-2 / 5)$ & -1 & - & -1 & II & - & - \\
\hline 31 Scirpoides holochenus (L.) Sojak (KK CO - 1/0) & -1 & - & - & II & - & II \\
\hline
\end{tabular}


Саксонов С.В., Васюков В.М., Казанцев И.В., Сенатор С.А 03.02.00 - общая биология Охраняемые растения на территории памятников природы Рачейского лесного массива..

\begin{tabular}{|c|c|c|c|c|c|c|}
\hline \multirow{3}{*}{$\begin{array}{c}\text { Названия растений, } \\
\text { природоохранный статус (по Красной книге Самарской области [19]) }\end{array}$} & \multicolumn{6}{|c|}{ Памятники природы } \\
\hline & $\Gamma$ & ИУ & $\mathrm{M}$ & PT & $\mathrm{PC}$ & $\mathrm{CK}$ \\
\hline & \multicolumn{6}{|c|}{ Встречаемость } \\
\hline \multicolumn{7}{|l|}{ Droseraceae } \\
\hline 32 2 Drosera rotundifolia L. (КК CO - 1/Б) & - & - & - & II & - & II \\
\hline \multicolumn{7}{|l|}{ Ericaceae } \\
\hline \begin{tabular}{l|l}
33 & Oxyccocus palustris Pers. (KK CO - 1/A)
\end{tabular} & - & - & - & III & - & - \\
\hline 34 Vaccinium myrtillus L. (КК CO - 1/Б) & $\mathrm{I}$ & - & $\mathrm{I}$ & II & - & - \\
\hline 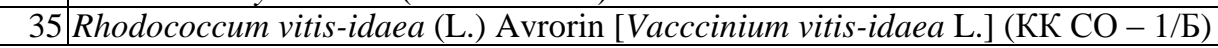 & II & - & II & III & - & - \\
\hline \multicolumn{7}{|l|}{ Fabaceae } \\
\hline \begin{tabular}{l|l|l}
36 & Latyrus niger (L.) Bernh. (KK CO - 1/0) \\
\end{tabular} & - & - & - & - & - & II \\
\hline \multicolumn{7}{|l|}{ Fumariaceae } \\
\hline \begin{tabular}{l|l|l}
37 & Corydalis solida (L.) Claiv. (нуждается в контроле) \\
\end{tabular} & III & III & III & II & III & II \\
\hline \multicolumn{7}{|l|}{ Gentianaceae } \\
\hline \begin{tabular}{l|l}
38 Gentiana cruciate L. (KK CO $-5 / \Gamma)$ \\
\end{tabular} & II & - & II & - & - & - \\
\hline \begin{tabular}{l|l}
39 & Gentiana pneumonante L. (KK CO - 5/Г) \\
\end{tabular} & - & II & - & - & - & II \\
\hline \multicolumn{7}{|l|}{ 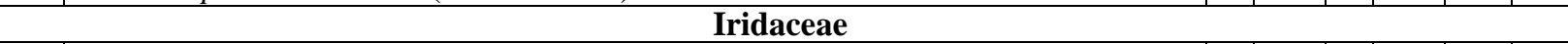 } \\
\hline \begin{tabular}{l|l}
40 & $*$ Iris aphylla L. $(\mathrm{KK} \mathrm{CO}-2 / \Gamma)$ \\
\end{tabular} & $\mathrm{I}$ & - & $\mathrm{I}$ & - & - & \\
\hline \begin{tabular}{l|ll}
41 & Iris pseudacorus L. (KK CO $-5 / \Gamma)$ \\
\end{tabular} & - & II & - & II & - & II \\
\hline \multicolumn{7}{|l|}{ T } \\
\hline 42 * Fritillaria ruthenica Wikstr. (КК CO $-5 / \Gamma$ ) & $\mathrm{I}$ & - & II & - & - & - \\
\hline \begin{tabular}{l|l}
43 & Lilium pilosiusculum (Freyn) Miscz. [L. martagon auct. non L.] (KK CO - 5/Г) \\
\end{tabular} & - & II & - & III & - & II \\
\hline \multicolumn{7}{|l|}{ Menyanthaceae } \\
\hline 44|Menyanthus trifoliata L. (KK CO - 2/A) & - & - & - & II & - & II \\
\hline Monotropaceae & & & & & & \\
\hline 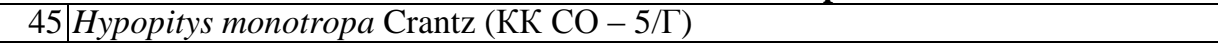 & $\mathrm{I}$ & - & II & III & - & $\mathrm{I}$ \\
\hline Nymphaeaceae & & & & & & \\
\hline 46 Nypha lutea (L.) Smith (KK CO $-5 / \Gamma)$ & - & - & - & II & - & II \\
\hline \begin{tabular}{l|l}
47 & Nymphaea candida J. Presl (KК CO - 5/Б) \\
\end{tabular} & - & - & - & II & - & II \\
\hline Onagraceae & & & & & & \\
\hline \begin{tabular}{l|l|l}
48 & Circaea alpina L. (KK CO - 1/Б) \\
\end{tabular} & - & - & & I & - & - \\
\hline Orchidaceae & & & & & & \\
\hline 49 * Cypripedium calceolus L. (KK CO - 3/Г) & - & - & - & I & - & - \\
\hline 50 Epipactis atrorubens (Hoffm. ex Bernh.) Schult. (KК CO - 3/Г) & $\mathrm{I}$ & - & II & - & - & $\mathrm{I}$ \\
\hline 51 Epipactis helleborine (L.) Cranz (KK CO $-5 / \Gamma)$ & II & II & II & III & II & III \\
\hline 52 Epipactis palustris (L.) Crantz. (KK CO $-3 / \Gamma)$ & - & - & - & II & - & II \\
\hline 53 Dactyloriza fuchsii (Druce) Soo (KK CO - 2/0) & - & - & - & II & - & II \\
\hline 54 Dactyloriza incarnata (L.) Soo (KK CO - 2/0) & - & - & - & II & - & II \\
\hline \begin{tabular}{l|l}
55 & Dactyloriza maculata (L.) Soo (KK CO - 2/0)
\end{tabular} & - & - & - & II & - & II \\
\hline 56 Gymnadenia conopsea (L.) R. Br. (KK CO - 2/Б) & - & - & - & I & - & $\mathrm{I}$ \\
\hline \begin{tabular}{l|l}
57 & Listera ovata (L.) R. Br. (КК CO - 1/Б) \\
\end{tabular} & - & - & - & I & - & - \\
\hline \begin{tabular}{l|l}
58 & Neottia nidus-avis (L.) Rich. (KK CO - 4/Г) \\
\end{tabular} & II & II & II & II & II & II \\
\hline 59 * Neottiantha cucullata (L.) Schlechter (КК CO - 1/Б) & - & - & - & II & - & - \\
\hline 60 * Orchis militaris L. (КК CO - 1/Б) & - & - & - & $\mathrm{I}$ & - & II \\
\hline $61 \mid$ Platanthera bifolia (L.) Rich. (КK CO - 4/Г) & II & II & II & III & II & III \\
\hline Parnassiaceae & & & & & & \\
\hline \begin{tabular}{l|l|l}
62 & Parnassia palustris L. (KK CO - 3/A) \\
\end{tabular} & - & - & - & II & - & II \\
\hline Poaceae & & & & & & \\
\hline 63 Bromopsis benekenii (Lange) Holub (KК CO - 3/Г) & II & I & II & - & - & - \\
\hline 64 Drymochloa sylvatica (Poll.) Holub [Festuca altissima All.] (КК CO - 2/Г) & $\mathrm{I}$ & - & $\mathrm{I}$ & - & - & - \\
\hline $65 \mid$ ! Cleistogenes squarrosa (Trin.) Keng. (нуждается в контроле) & II & - & II & - & - & - \\
\hline 66 ! Molinia caerulea (L.) Moench (нуждается в контроле) & - & - & - & III & - & III \\
\hline \begin{tabular}{l|l}
67 & $\begin{array}{l}\text { Neoholubia pubescens (Huds.) Tzvelev [Helictotrichon pubescens (Huds.) Pilg.] } \\
\text { (KK CO }-5 / \Gamma)\end{array}$
\end{tabular} & 1 & - & II & - & - & \\
\hline 68 Leersia oryzoides (L.) Sw. (KK CO $-5 / \Gamma)$ & - & II & - & - & - & II \\
\hline \begin{tabular}{l|l}
69 & Stipa pennata L. (КК CO - 5/Б) \\
\end{tabular} & $\mathrm{I}$ & - & $\mathrm{I}$ & - & $\mathrm{I}$ & - \\
\hline Polemoniacaea & & & & & & \\
\hline \begin{tabular}{l|l}
70 & Polemonium caerulea L. (KK CO $-5 / \Gamma)$ \\
\end{tabular} & - & II & - & II & - & II \\
\hline Potamogetonaceae & & & & & & \\
\hline \begin{tabular}{l|l|}
71 & Ponamogeton gramineus L. (KK CO $-5 / \Gamma)$ \\
\end{tabular} & - & - & - & - & - & II \\
\hline Primulaceae & & & & & & \\
\hline \begin{tabular}{l|l}
72 & Trientalis europaea L. (KK CO - 1/Б) \\
\end{tabular} & - & II & - & II & - & II \\
\hline Pyrolaceae & & & & & & \\
\hline \begin{tabular}{l|l}
73 & Cimaphilla umbellata (L.) W. Barton (KK CO $-5 / \Gamma)$ \\
\end{tabular} & II & - & II & III & - & - \\
\hline 74 Moneses uniflora (L.) A. Gray (KK CO - 1/Г) & $\mathrm{I}$ & - & I & 1 & - & - \\
\hline 75 Pyrola chlorantha Sw. $(\mathrm{KK} \mathrm{CO}-5 / \Gamma)$ & $\mathrm{I}$ & $\mathrm{I}$ & 1 & II & 1 & - \\
\hline 76 Pyrola minor L. $(\mathrm{KK} \mathrm{CO}-3 / \Gamma)$ & - & - & - & III & - & - \\
\hline \begin{tabular}{l|l|l|}
77 & Pyrola rotundifolia $\mathrm{L} .(\mathrm{KK} \mathrm{CO}-5 / \Gamma)$ \\
\end{tabular} & $\mathrm{I}$ & $\mathrm{I}$ & 1 & II & 1 & - \\
\hline
\end{tabular}




\section{Ranunculaceae}

$78 \mid$ Adonanthe vernalis $(\mathrm{L}$.$) Spach [Chrysocyathus vernalis (L.) Holub] (\mathrm{KK} \mathrm{CO} \mathrm{-} \mathrm{5/ \Gamma )}$

79 ! Delphinium cuneatum Steven ex DC. (нуждается в контроле)

80 ! Caltha palustris L. (нуждается в контроле)

81 Pulsatilla patens (L.) Mill. (KK CO - 5/A)

82 Ranunculus lingua L. (KK CO $-4 / \Gamma)$

83 Ranunculus meyerianus Rupr. (KK CO $-3 / \Gamma$ )

84 Trollius europaeus L. (KK CO - 5/Б)

\begin{tabular}{r|l|}
\hline 85 & Comarum palustre L. (KK CO - 3/Б) \\
\hline 86 & Potentilla erecta (L.) Raeusch. (KK CO - 3/Б) \\
\hline
\end{tabular}

86 Potentilla erecta (L.) Raeusch. (KK CO - 3/Б)

87 Populus alba L. (KK CO - 5/Б)

Salicacaea Встречаемость

88 ! Salix acutifolia Willd. (нуждается в контроле)

89 ! Salix alba L. (нуждается в контроле)

90 Salix lapponum L. (KK CO $-2 / \Gamma)$

91 Salix rosmarinifolia L. (KK $\mathrm{CO}-3 / \mathrm{5}$ )

\begin{tabular}{|c|c|c|c|c|c|c|}
\hline \multicolumn{7}{|c|}{ Scheuchzeriaceae } \\
\hline 92!! Scheuchzeria palustris L. (нуждается в контроле) & - & - & -1 & II & - & II \\
\hline \multicolumn{7}{|c|}{ Scrophulariaceae } \\
\hline 93! Pedicularis palustris L. (нуждается в контроле) & - & - & -1 & II & - & II \\
\hline 94! Verbascum thapsus L. (нуждается в контроле) & II & - & II & - & II & - \\
\hline 95 Veronica officinalis L. (KK CO - 2/B) & -1 & - & - & III & - & III \\
\hline
\end{tabular}
95 Veronica officinalis L. (KK CO - 2/B)

\begin{tabular}{|c|c|c|c|c|c|c|}
\hline \multicolumn{7}{|l|}{ Sparganiaceae } \\
\hline 96 Sparganium minimum Wallr. (KК CO -3/Г) & - & - & - & II & - & II \\
\hline \multicolumn{7}{|l|}{ Thymelaceae } \\
\hline \begin{tabular}{l|l|l|}
97 Daphe mezereum L. $($ КK CO $-5 / \Gamma)$ \\
\end{tabular} & II & II & II & $\mathrm{I}$ & II & $\mathrm{I}$ \\
\hline \multicolumn{7}{|l|}{ Valerianaceae } \\
\hline \begin{tabular}{l|l} 
Valeriana wolgensis Kazak. (КК CO - 5/Б) \\
\end{tabular} & -1 & - & - & - & & II \\
\hline \multicolumn{7}{|l|}{ Violaceae } \\
\hline 99 Viola epipsila Ledeb. (КК CO - 1/0) & - & - & - & II & - & - \\
\hline 100 Viola riviniana $\mathrm{Rchb} .(\mathrm{KK} \mathrm{CO}-4 / \Gamma)$ & II & I & II & - & I & - \\
\hline \multicolumn{7}{|l|}{$\begin{array}{c}\text { Голосеменные } \\
\text { Cupressaceae }\end{array}$} \\
\hline 101 Juniperus communis L. (КК CO - 1/A) - по-видимому, исчез & - & - & - & - & - & \\
\hline \multicolumn{7}{|l|}{$\begin{array}{l}\text { Плауновидные } \\
\text { Lycopodiaceae }\end{array}$} \\
\hline 102 Diphasiastrum complanatum (L.) Holub (KK CO - 1/A) & - & - & - & II & - & - \\
\hline 103 Diphasiastrum zeilleri (Rony) Holub (нуждается в контроле) & - & - & - & $\mathrm{I}$ & - & - \\
\hline 104 Lycopodium annotinum L. (КK CO - 1/A) & - & - & - & II & - & I \\
\hline 105 Lycopodium clavatum L. (KK CO - 1/A) & - & - & - & II & - & I \\
\hline
\end{tabular}

105 Lycopodium clavatum L. (KK CO - 1/A)

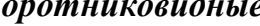

106 Asplenium septentrionale (L.) Hoffm. (KK CO - 1/0)

Aspleniaceae

107 Athyrium felix-femina (L.) Roth (KK CO $-5 / \Gamma)$

108 Gymnocarpium dryopteris (L.) Newm. (KK CO - 5/Г)

109 Gymnocarpium robertianum (Hoffm.) Newm. (KK CO - 2/Г)

\begin{tabular}{|c|c|c|c|c|c|c|}
\hline \multicolumn{7}{|l|}{ Botrychiaceae } \\
\hline \begin{tabular}{l|l|l}
110 Botrichium lunaria (L.) Sw. (KK CO $-2 / \Gamma)$ \\
\end{tabular} & I & - & -1 & - & - & - \\
\hline \multicolumn{7}{|l|}{ Dryopteridaceae } \\
\hline 111 Dryopteris cristata (L.) A. Gray (KK CO $-2 / \Gamma)$ & - & I & - & III & - & III \\
\hline \multicolumn{7}{|l|}{ Onocleaceae } \\
\hline 112 Matteucia struthiopteris (L.) Tod. (KK CO $-5 / \Gamma)$ & - & III & - & II & - & II \\
\hline \multicolumn{7}{|l|}{ Polypodiaceae } \\
\hline 113 Polypodium vulgare L. (KK CO - 1/Б) & I & - & - & - & - & \\
\hline \multicolumn{7}{|l|}{ Salviniaceae } \\
\hline $114 \mid$ Salvinia natans (L.) All. (KK CO - 3/B) & - & - & - & II & - & - \\
\hline \multicolumn{7}{|l|}{ Thelypteridaceae } \\
\hline 115 Phegopteris connectilis (Michx.) Watt (KK CO - 1/0) & - & - & - & I & - & - \\
\hline
\end{tabular}

Примечание. Памятники природы: $\Gamma-$ «Гремячий»; ИУ - «Истоки р. Усы»; $M-$ «Малоусинские нагорные сосняки и дубравы»; $P T$ - «Рачейская тайга»; $P C$ - «Рачейские скалы»; $C K-$ «Семь ключей». Римскими цифрами приведена оценка встречаемости: $I$ - очень редко; $I I$ - редко; $I I I$ - изредка. Знаком «!» отмечены виды, не внесенные в Красную книгу Самарской области, но нуждающиеся в контроле и наблюдении. Знаком «*» отмечены виды, занесенные в Красную книгу Российской Федерации [18]. 
Саксонов С.В., Васюков В.М., Казанцев И.В., Сенатор С.А.

В Красной книге Самарской области [19] для бассейна р. Усы приводились Cotoneaster alaunicus Golitsin, Dactyloriza longifolia (L.) Aver. и Jurinea ewersmannii Bunge - нахождение их в регионе нуждается в дополнительных исследованиях.

Ранее $[18 ; 30 ; 31]$ был предложен фитосозологический рейтинг памятников природы регионального значения, в котором охраняемые природные объекты верховий реки Уса занимают довольно высокие позиции: «Рачейская тайга» (150 баллов - первое место в рейтинге), «Семь ключей» (131 балл, 15-16 место), «Рачейские скалы» (118 баллов, 34 место), «Малоусинские нагорные сосняки и дубравы» (109 баллов, 49-50 место), «Гремячий» (101 балл, 69-70 место), «Истоки р. Уса» (99 баллов, 73-75 место). Предложенное укрупнение ряда памятников природы Рачейского лесного массива не скажется на их положении в фитосозологическом рейтинге.

Представленные материалы будут полезны авторскому коллективу, работающему над вторым изданием Красной книги Самарской области, выход которого планируется в 2017 г.

\section{СПИСОК ЛИТЕРАТУРЫ:}

1. Река Уса [Электронный ресурс] // Государственный водный реестр. - http://textual.ru/gvr/ index.php?card $=185068$.

2. Ресурсы поверхностных вод СССР: Гидрологическая изученность. Т. 12. Нижнее Поволжье и Западный Казахстан. Вып. 1. Нижнее Поволжье / под ред. О.М. Зубченко. Л.: Гидрометеоиздат, 1966. $287 \mathrm{c}$.

3. Розенберг Г.С., Саксонов С.В., Евланов И.А., Зинченко Т.Д., Матвеев В.И., Быкова С.В., Герасимов Ю.Л., Головатюк Л.В., Горбунов М.Ю., Горохова О.Г., Иванова А.В., К Конева Н.В., К Краснова Е.С., Лысенко Т.М., Номоконова В.И., Романова Е.П., Соловьева В.В., Уманская М.В., Шерышева Н.Г., Юрицына Н.В. Голубая книга Самарской области: редкие и охраняемые гидробиоценозы / под ред. чл.-корр. РАН Г.С. Розенберга и д-ра биол. наук С.В. Саксонова. Самара: Самарский научный центр РАН, 2007. $200 \mathrm{c}$.

4. Физико-географическое районирование Среднего Поволжья / под ред. А.В. Ступишина. Казань: Изд-во Казан. ун-та, 1964. 197 с.

5. Захаров А.С. Рельеф Куйбышевской области: пособие по краеведению / под ред. А.В. Ступишина. Куйбышев: Куйбышевское книжное издательство, $1971.87 \mathrm{c}$.

6. Сенатор С.А. Природное районирование Самарской области в работах различных исследователей // Самарская Лука: проблемы региональной и глобальной экологии. 2015. Т. 24, № 1. С. 6-37.

7. Благовещенский В.В. Растительность Приволжской возвышенности в связи с ее историей и рациональным использованием. Ульяновск: УлГУ, 2005. $715 \mathrm{c}$.

8. Сенатор С.А. Болота Самарской области - общая характеристика, особенности, заторфованность // Самарская Лука: проблемы региональной и глобальной экологии. 2016. Т. 25, № 4. С. 44-65.
9. Оробинская Т.В., Варенов Д.В. Памятники природы северо-запада Сызранского района в комплексной практике студентов географического отделения СГПУ // Краеведческие записки. Вып. 13. Самара, 2004. С. 131-144.

10. Варенов Д.В., Сименко К.Н., Оробинская Т.В. Останцы верховий р. Усы и история их формирования // Краеведческие записки. Вып. 13. Самара, 2004. C. $145-162$.

11. Сименко К.Н., Варенов Д.В. Природно-туристические объекты окрестностей села Смолькино Сызранского района // Исследования в области биологии и методики её преподавания: межвузовский сборник науч. тр. Вып. 3(2). Самара: Изд-во СГПУ, 2003. C. $120-128$.

12. Сименко К.Н., Журавлева С.Н. Особенности геолого-геоморфологического строения северо-запада Сызранского района // Исследования в области естественных наук и образования: межвуз. сб. науч.исслед. работ преподавателей и студентов. Самара: Изд-во СГПУ, 2005. С. 279-280.

13. Новоженин Ю., Плаксина Т. Малоусинские нагорные сосняки и дубравы // «Зеленая книга» Поволжья: Охраняемые природные территории Самарской области. Самара: Книжное изд-во, 1995. С. 269271.

14. Саксонов С.В., Сенатор С.А., Васюков В.М., Иванова А.В., Раков Н.С. Материалы к флоре памятника природы «Малоусинские нагорные сосняки и дубравы» // Эколого-географические проблемы регионов России: мат-лы IV всерос. науч.-практич. конференции, посвящённой 130-летию со дня рождения первого заведующего кафедрой географии ПГСГА, профессора К.В. Полякова. Самара: ПГСГА, 2013. C. 294-301.

15. Саксонов С.В., Лысенко Т.М., Ильина В.Н., Конева Н.В., Лобанова А.В., Матвеев В.И., Митрошенкова А.Е., Симонова Н.И., Соловьева В.В., Ужамецкая Е.А., Юрицына Н.А. Зеленая книга Самарской области: редкие и охраняемые растительные сообщества / под ред. чл.-корр. РАН Г.С. Розенберга и д-ра биол. наук С.В. Саксонова. Самара: Самар. науч. центр РАН, 2006. $201 \mathrm{c}$.

16. Особо охраняемые природные территории регионального значения Самарский области: мат-лы Государственного кадастра / сост. А.С. Паженков. Самара: ООО «Фронт», 2013. 502 с.

17. Саксонов С.В. Теоретические основы регионального флористического мониторинга. Тольятти: Кассандра. 2017. 532 с.

18. Красная книга Российской Федерации (растения и грибы). М., 2008. 885 с.

19. Красная книга Самарской области. Т. 1. Редкие виды растений, лишайников и грибов. Тольятти, 2007. $372 \mathrm{c}$.

20. Симонова Н.И. Влияние природных и антропогенных факторов на растительный покров сосновых лесов Самарской области: дис. ... канд. биол. наук. Тольятти, 2001. 269 с.

21. Симонова Н.И., Матвеев В.И., Хлебодарова Н.В. Охрана флоры и растительности Рачейского бора // 
Региональные экологические проблемы и возможные пути их реализации: тез. докл. межвуз. научно-практ. конф. студентов и молодых специалистов. Самара, 1994. С. 11-12.

22. Ильина Н.С., Соловьева В.В., Симонова Н.И. Эколого-флористическая характеристика болот Рачейского бора // Гидроботаника - 2000: тез. докл. $\mathrm{V}$ всерос. конф. по водным растениям. Борок, 2000. C. $147-148$.

23. Калашникова О.В. Новые данные по флоре правобережья Волги в Самарской области // Известия Самарского научного центра Российской академии наук. 2013. Т. 15, № 3(2). С. 836-840.

24. Калашникова О.В., Плаксина Т.И. Особенности флоры высших растений Рачейского бора Самарской области // Вестник СамГУ. Естеств.-науч. сер. 2007. № 8(68). С. 69-79.

25. Калашникова О.В., Плаксина Т.И., Калашникова Л.В. К познанию флоры памятника природы «Малоусинские нагорные сосняки и дубравы» // Известия Самарского научного центра Российской академии наук. 2009. Т. 11, № 1(3). С. 433-435.

26. Калашникова О.В., Попова Д.С. Уникальная флора памятника природы «Рачейские скалы» в Самарской области // Экологический сборник 2: труды молодых учёных Поволжья / под ред. профессора С.В. Саксонова. Тольятти: ИЭВБ РАН, 2009. С. 233235.

\section{PROTECTED PLANTS ON THE TERRITORY OF THE RACHEISKII FOREST NATURAL MONUMENTS (SAMARA REGION)}

(C) 2017

Saksonov Sergey Vladimirovich, doctor of biological sciences, professor, deputy director for science, head of Phytodiversity Problems Laboratory

Vasjukov Vladimir Mikhailovich, candidate of biological sciences, researcher of Phytodiversity Problems Laboratory

Institute of Ecology of the Volga River Basin of Russian Academy of Sciences (Togliatti, Samara Region, Russian Federation)

Kazantsev Ivan Victorovich, candidate of biological sciences, dean of Faculty of Natural Sciences and Geography,

associate professor of Chemistry, Geography and Methods of Teaching Department Samara State University of Social Sciences and Education (Samara, Russian Federation)

Senator Stepan Aleksandrovich, candidate of biological sciences, senior researcher of Phytodiversity Problems Laboratory

Institute of Ecology of the Volga River Basin of Russian Academy of Sciences

(Togliatti, Samara Region, Russian Federation)

Abstract. The paper contains species composition of the rare taxa growing in specially protected natural areas in the Samara Region - Gremiachii, the source of Usa river, Malousinskie upland pine and oak forests, Racheiskaia taiga, Racheiskie skaly and Seven springs, located in the Racheiskii forest (upper reaches of the Usa river basin). The authors assess their occurrence in the protected areas. They have established that 98 species of rare vascular plants that included in the Red Book of the Samara Region grow here, among them 4 species are included in the Red Book of the Russian Federation (Iris aphylla L., Fritillaria ruthenica Wikstr., Cypripedium calceolus L., Neottiantha cucullata (L.) Schlechter). Another 17 species need constant monitoring and surveillance. Previously presented for the Usa river basin Cotoneaster alaunicus Golitsin, Dactyloriza longifolia (L.) Aver. and Jurinea ewersmannii Bunge have not been found, their location in the region requires additional research. For the revision of rare plant species the authors have used published materials and unpublished materials of expeditionary research integrated in Information-analytical system Salix. The obtained materials make it possible to correct the natural monuments system by combining identical natural-territorial complexes.

Keywords: specially protected natural territories of regional value; natural monuments; rare species; vascular plants; Red book of Samara Region; Information-analytical system Salix; upper reaches of Usa river basin; Racheiskii forest; Samara Region. 